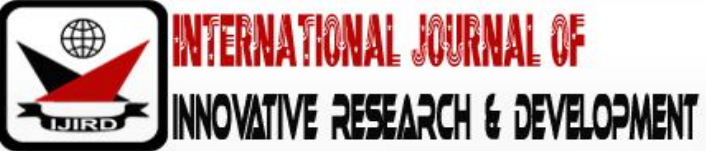

ISSN 2278 - 0211 (Online)

\section{GC And FTIR Studies Of Hexane and Ethanol Extracts of Calophyllum Inophyllum, Nigeria}

David. O. Adekunle
Assistant Lecturer, Department of Chemistry and Industrial Chemistry,
Bowen University Iwo, Nigeria
Anointing O. Olanrewaju
Student, Department of Chemistry and Industrial Chemistry,
Bowen University Iwo, Nigeria
Adeshina I. Odugbemi
Assistant Lecturer, Department of Biochemistry, Bowen University Iwo, Nigeria

\begin{abstract}
:
This study investigates the phytochemical constituents in ethanol and hexane seed extract of Calophyllum inophyllum. The seed extracts contains saponins, tannins, glycosides, flavonoids, and steroids and absence of alkaloids and anthraquinones.

The FTIR study shows various absorptions in the two extracts of Callophylum inophyllum. A strong absorption at $3265.3 \mathrm{~cm}^{-1}$ corresponds to $\mathrm{O}-\mathrm{H}$ stretch which was observed in the ethanol extract only. $\mathrm{C}=0$ stretch was observed in $1742.5 \mathrm{~cm}^{-1}$ and $1701.5 \mathrm{~cm}^{-1}$ in both extracts. Other strong absorptions were observed at $2853.3 \mathrm{~cm}^{-1}, 2929.7 \mathrm{~cm}^{-1}$ $2922.2 \mathrm{~cm}^{-1}, 2976.3 \mathrm{~cm}^{-1}, 1578.5 \mathrm{~cm}^{-1}, 1459.3 \mathrm{~cm}^{-1}, 1347.4 \mathrm{~cm}^{-1}, 1235.6 \mathrm{~cm}^{-1}$ and $1312.0 \mathrm{~cm}^{-1}$ in both extracts. $1407.1 \mathrm{~cm}^{-}$ $1,1449.9 \mathrm{~cm}^{-1}$ and $1116.3 \mathrm{~cm}^{-1}$ in the ethanol extract only. $3006.1 \mathrm{~cm}^{-1}, 1654.9 \mathrm{~cm}^{-1}, 1625.1 \mathrm{~cm}^{-1}$, and $1377.3 \mathrm{~cm}^{-1}$ in hexane extract only. $1079.1 \mathrm{~cm}^{-1}, 1097.7 \mathrm{~cm}^{-1}, 1118.2 \mathrm{~cm}^{-1}$ and $1159.2 \mathrm{~cm}^{-1}$ in both extracts. Other absorptions observed are $1039.9 \mathrm{~cm}^{-1} 855.2 \mathrm{~cm}^{-1}, 721.2 \mathrm{~cm}^{-1}, 928.1 \mathrm{~cm}^{-1}, 885.2 \mathrm{~cm}^{-1}$, and $697.0 \mathrm{~cm}^{-1}$.

Gas Chromatography analysis identified the presence of eight fatty acids in Calophyllum inophyllum seed extract namely: Lauric (3.19\%), Pentadecanoic (0.3\%), Stearic (8.03\%), Oleic (17.63\%), Linoleic (16.67\%), Arachnidic (0.2\%), Behenic (0.05\%), Lignoceric (0.04\%) and absence of Tridecanoic, Myristic, Palmitic, Tricosnoic.

This study concludes that the seed extracts of Calophylluminophyllum contain large amounts of phytochemicals and beneficial fatty acids with a possibility of wide range application taking advantage of the biological activities such as antimicrobial, antiviral, cytotoxic, analgesic and against other disorders in favor of public health.
\end{abstract}

Keywords: Fatty acids, FTR, GC, linoleic acid, oleic acid

\section{Introduction/ Background}

Calophyllum innophyllum is an evergreen tree (also known as "Alexandrian Laurel") widely dispersed throughout the tropics and popular for its timber and seed oil products. The plant tolerates harsh environmental conditions of acidity, salinity, drought and a wide temperature range, requiring little maintenance (Friday and Okano, 2006; Hathurusingha and Ashwath 2007). Among its many economic uses is the high commercial demand for Calophyllum innophyllum seed oil from pharmaceutical industry.

The genus Calophyllum is a large group of tropical trees of up to 200 different species (Oliver-Bever, 1986) but Calophyllum innophyllum is the most abundant and has a rich reserve of secondary metabolites like triterpenes and steroids, benzopyrans, xanthones, coumarins and flavonoids (Govindachari et al., 1967; Sartori et al., 1999; Ito et al., 2003; Ma et al., 2004). Due to its rich phytochemicals, studies have shown that Calophyllum innophyllum has medicinal properties ranging from antimalaria (Hay et al., 2004), antibacterial (Yimdjo et al., 2004), to anticancer (Itoigawa et al., 2001). The leaves are used in treating migraine, dermatosis, urticaria (hives) and eczema (Prabakaran and Britto., 2012). The oil extracted from the seeds is claimed to be analgesic and is used for the treatment of leprous neuritis, rheumatism and gout. The oil also has the ability to accelerate wound healing and render the skin healthy (Akter et al., 2017). Moreover, there are reports of isolated xanthones and coumarins having anti-HIV-1 properties (Laure et al., 2008; Patil et al., 1993), enabled through inhibition of HIV-1 reverse transcriptase (McKee et al., 1998; Sekino et al., 2004). Furthermore, the rising demand for renewable energy makes Calophyllum innophyllum a target for potential biodiesel product because of its oil content.

For its diversity, the kernel of Calophyllum innophyllum is rich in lipids. Five kilograms of oil may be extracted from a hundred kilograms of nuts (Friday and Okano, 2006). It has been reported that fatty acid composition may influence the quality of the resultant biodiesel (Ramos et al., 2009). In addition, the presence unsaturated fatty acids like 
omega-3 and omega-6 may give credence to anti-inflammatory properties of Calophyllum innophyllum (Nowak, 2010). Calophyllum inophyllum is noted to have healing properties. The natives in New Caledonia and in Samoa utilize these leaves for treating skin inflammations, leg ulcers and wounds (Quisumbing., 1951).Calophyllum inophyllum has been used for treatment of various diseases such as eye diseases, rheumatism, and inflammation. The leaves are used in migraine, dermatosis, urticaria (hives) and eczema and are more affordable than purchasing modern pharmaceuticals (Prabakaran and Britto., 2012). This study gives insights to the medicinal uses, functional groups and phytochemical constituents of seed extracts of Calophyllum inophyllum from Nigeria.

Interestingly, neither the fatty acid composition nor the phytochemical properties of the Nigerian species of Calophyllum innophyllum has been reported.

\section{Materials and Methods}

\subsection{Plant Collection, Preparation and Extraction}

The matured seeds of Calophyllum inophyllum (Balltree) were obtained from Ademola Ishola hall, Bowen University, Iwo, Osun state, Nigeria, during the month of March, 2018. The seeds obtained were cleaned, deshelled, pulverized and stored in dark airtight container. Approximately 200 g Calophyllum inophyllum seeds were collected and blended. This is to ensure powdered plant materials have maximum surface area contact with solvents for an efficient extraction.

The powdered seed was soaked in hexane for 24 hours at room temperature. It was noted that plant extracts should not be stored in solvent for long periods, because this will increase the risk of decomposition of extract constituents. After 24 hours, the mixture was concentrated; the extract was soaked in hexane for another 24 hours and weighed. The hexane crude extract was filtered and solvent was evaporated under reduced pressure via a rotary evaporator. The steps were repeated using Ethanol as a solvent.

\section{Chemical Analysis}

\subsection{Gas Chromatography (GC)}

Gas Chromatography (GC) of the samples were recorded at the Central laboratory Bowen University, Iwo using a 7890B Aligent Technologies Gas Chromatgraphy.

\subsection{FTIR Studies}

Fourier Transform Infrared spectra (FTIR) of the samples were recorded at Bowen University, Iwo, Central laboratory using a computerized Cary 630 spectrometer, Agilent technologies in the range of 4000-650/ cm.

\subsection{Phytochemical Investigation of Hexane and Ethanol Extract of the Seeds of C.Inophyllum}

Phytochemical tests were studied on the extracts using standard procedure described by Sofowora, Trease and Evans and Harbone in 1996,1989 and 1973 respectively.

\subsection{Qualitative Analysis on Phytochemical Constituents}

- Test for Alkaloids: From each extracts, one (1) ml was measured and was added to $2 \mathrm{ml}$ of dilute $\mathrm{H}_{2} \mathrm{SO}_{4}$, it was then filtered. $1 \mathrm{ml}$ of Meyer's reagent was added. A white or creamy precipitate indicates the presence of alkaloids which was absent.

- Test for Saponins: $1 \mathrm{ml}$ of each extracts was added to $2 \mathrm{ml}$ of distilled water and it was vigorously shaken for 15 minutes. Formation of $1 \mathrm{~cm}$ foam confirmed the presence of saponins.

- Test for tannins: $1 \mathrm{ml}$ of each extracts was placed in a test tube and few drops of $5 \%$ ferric chloride solution $\left(\mathrm{FeCl}_{3}\right)$ was added and observed for bluish-black coloration, which showed the presence of tannins.

- Test for Glycosides: $1 \mathrm{ml}$ of extracts was added to $3 \mathrm{ml}$ of chloroform $\left(\mathrm{CHCl}_{3}\right)$ and $2 \mathrm{ml}$ of $10 \%$ ammonia $\left(\mathrm{NH}_{3}\right)$ was also added. A pink coloration represented the presence of Glycosides.

- Test for Anthraquinone: $1 \mathrm{ml}$ of each extract was added to $5 \mathrm{ml}$ of $\mathrm{CHCl}_{3}$ and vigorously agitated for 5 minutes, it was then filtered. $2 \mathrm{ml}$ of $10 \%$ ammonia solution was added to the filtered solution and the mixture was shaken. A bright pink color proves the presence of Anthraquinone which was absent.

\section{Results} table below.

Qualitative analysis carried out for the hexane and ethanol extract of the C. inophyllum seeds is summarized in the 


\begin{tabular}{|c|c|c|}
\hline Phytochemicals & Hexane & Ethanol \\
\hline \multicolumn{3}{|l|}{ Alkaloids } \\
\hline Saponins & + & + \\
\hline Tannins & + & + \\
\hline Glycosides & & + \\
\hline \multicolumn{3}{|l|}{ Anthraquinone } \\
\hline Flavonoids & + & \\
\hline Steroids & + & + \\
\hline
\end{tabular}

Table 1: Results of the Qualitative Analysis on Phytochemical Constituents

Key: +. Present --: Absent

The FTIR results of the hexane and ethanol extracts showing the peak values, bond stretch and functional groups.

\begin{tabular}{|c|c|c|c|c|c|}
\hline \multicolumn{3}{|c|}{ Hexane } & \multicolumn{3}{|c|}{ Ethanol } \\
\hline $\begin{array}{c}\text { Peak Values } \\
(\mathrm{Cm}-1)\end{array}$ & $\begin{array}{c}\text { Bond } \\
\text { Stretch }\end{array}$ & $\begin{array}{l}\text { Functional } \\
\text { Groups }\end{array}$ & $\begin{array}{c}\text { Peak Values } \\
(\mathrm{Cm}-1)\end{array}$ & $\begin{array}{l}\text { Bond } \\
\text { Stretch }\end{array}$ & $\begin{array}{c}\text { Functional } \\
\text { Groups }\end{array}$ \\
\hline 3006.1 & $\begin{array}{c}=\mathrm{C}-\mathrm{H} \\
\text { stretch }\end{array}$ & Alkene & 3265.3 & $\mathrm{O}-\mathrm{H}$ & Phenol \\
\hline 2853.3 & $\begin{array}{c}\text { C-H } \\
\text { stretch }\end{array}$ & Alkane & 2929.7 & $\begin{array}{l}\text { C-H } \\
\text { stretch }\end{array}$ & Alkane \\
\hline 2922.2 & $\begin{array}{c}\mathrm{C}-\mathrm{H} \\
\text { Stretch }\end{array}$ & Alkane & 2976.3 & $\begin{array}{c}\mathrm{C}-\mathrm{H} \\
\text { stretch }\end{array}$ & Alkane \\
\hline 1742.5 & $\begin{array}{c}\mathrm{C}=\mathrm{O} \\
\text { stretch }\end{array}$ & Carbonyl & 1701.5 & $\begin{array}{c}\mathrm{C}=0 \\
\text { stretch }\end{array}$ & Carbonyl \\
\hline 1654.9 & $\begin{array}{c}\mathrm{C}=\mathrm{C} \\
\text { stretch }\end{array}$ & Alkene & 1578.5 & $\begin{array}{c}\mathrm{C}=\mathrm{C} \\
\text { stretch }\end{array}$ & Aromatic \\
\hline 1625.1 & $\begin{array}{c}\mathrm{C}=\mathrm{C} \\
\text { stretch }\end{array}$ & Alkene & 1407.1 & $\begin{array}{c}\mathrm{C}-\mathrm{H} \\
\text { bending }\end{array}$ & Alkane \\
\hline 1347.4 & $\begin{array}{c}\text { C-N } \\
\text { stretch }\end{array}$ & Amine & 1449.9 & $\begin{array}{c}\mathrm{C}-\mathrm{H} \\
\text { bending }\end{array}$ & Alkane \\
\hline 1235.6 & $\begin{array}{c}\text { C-N } \\
\text { stretch }\end{array}$ & Amine & 1312.0 & $\begin{array}{c}\mathrm{C}-\mathrm{N} \\
\text { stretch }\end{array}$ & Amine \\
\hline 1459.3 & $\begin{array}{c}\mathrm{C}=\mathrm{C} \\
\text { Stretch }\end{array}$ & Aromatic & 1039.9 & C-F & Alkyl halide \\
\hline 855.2 & $\begin{array}{c}=\mathrm{CH} \\
\text { bending }\end{array}$ & Alkene & 1079.1 & $\begin{array}{c}\text { C-O } \\
\text { Stretch }\end{array}$ & Ether \\
\hline 1377.3 & $\begin{array}{c}\mathrm{N}-\mathrm{O} \\
\text { stretch }\end{array}$ & Nitro $=$, & 1116.3 & $\begin{array}{c}\mathrm{C}-\mathrm{H} \\
\text { bending }\end{array}$ & Alkane \\
\hline 721.2 & $\begin{array}{l}=\mathrm{C}-\mathrm{H} \\
\text { stretch }\end{array}$ & Alkene & 928.1 & $\begin{array}{c}=\mathrm{C}-\mathrm{H} \\
\text { stretch }\end{array}$ & Alkene \\
\hline 1097.7 & $\begin{array}{c}\text { C-O } \\
\text { stretch }\end{array}$ & Ether & 885.2 & $\begin{array}{c}=\mathrm{C}-\mathrm{H} \\
\text { Stretch }\end{array}$ & Alkene \\
\hline 1118.2 & $\begin{array}{c}\text { C-O } \\
\text { stretch }\end{array}$ & Ether & & & \\
\hline 697.0 & $\begin{array}{c}\mathrm{C}-\mathrm{Cl} \\
\text { Stretch }\end{array}$ & Alkyl halide & & & \\
\hline 1159.2 & $\begin{array}{c}\text { C-O } \\
\text { stretch }\end{array}$ & Ether & & & \\
\hline
\end{tabular}

Table 2: FTIR Result of Hexane and Ethanol Seeds Extract of C. Inophyllum

Results of the GC analysis showing the peak area and the percentage composition of the various fatty acids pressent in the hexane extract. 


\begin{tabular}{|c|c|c|c|}
\hline Fatty acids & $\begin{array}{c}\text { Peak Area } \\
\mathbf{0 . 0 3 1 3 \%} \text { Standard }\end{array}$ & \multicolumn{2}{|c|}{ Extract + Hexane } \\
\hline & & P/A & \% \\
\hline Lauric & 4.63 & 47.26 & 3.19 \\
\hline Tridecanoic & 12.60 & - & - \\
\hline Myristic & 186.27 & - & - \\
\hline Pentadecanoic & 3.82 & 3.21 & 0.3 \\
\hline Palmitic & 130.82 & - & - \\
\hline Stearic & 66.69 & 1710.45 & 8.03 \\
\hline Oleic & 66.93 & 3770.57 & 17.63 \\
\hline Linoleic & 81.16 & 4323.79 & 16.67 \\
\hline Arachnidic & 198.84 & 112.28 & 0.2 \\
\hline Behenic & 209.34 & 32.74 & 0.05 \\
\hline Tricosnoic & 219.63 & - & - \\
\hline Lignoceric & 229.82 & 31.23 & 0.04 \\
\hline
\end{tabular}

Table 3: GC Result of Hexane Seeds Extract of C. Inophyllum

\section{Discussion}

Phytochemistry, generally termed "plant chemistry", is a study of chemical constituents that are naturally occurring in plants. The term secondary metabolites are referring to the phytochemicals that are synthesized by specialized plants cells in a trace quantity via secondary metabolism pathway. Each plant family, genus and species produces characteristic phytochemicals. Secondary metabolites have no obvious function in a plant's primary metabolism as well as in photosynthesis and reproduction. They may possess an ecological role, as pollination attractants, represent chemical adaptions to environmental stresses, or coordinate the development of the whole plant defense mechanisms. For instance, plants produce toxic phytoalexins to kill pathogenic microbes and insects (Monika et.al., 2008). A wide variety of active phytochemicals have been identified and found to possess a broad range of biological activities such as antimicrobial, antiviral, antioxidative, anti-malarial and antitumor properties ( $\mathrm{Su}$ et al., 2008). Table 1 shows the results of the phytochemical screening of the plant seeds which revealed the presence of saponins, tannins, glycosides, flavonoids and steroids and the absence alkaloids and anthraquinones.

Characteristics of saponins includes formation of foams in aqueous solution, cholesterol binding properties (Sodipo and Akiniyi., 2000).

Tannins have antibacterial and antihelminthic properties (Hedberg et al., 1983). Tannins are reported to have physiological effects such as anti-irritant, antisecretolytic, antimicrobial and antiparasitic effects. Plants that contains tannins are used to treat diarrhea, inflammations of mouth and throat and slightly injured skins (Westendarp., 2006).

Flavonoid indicates naturally occurring phenolic compounds, with beneficial effects such as antioxidant and neutralizing free radicals in the human diet. Flavonoids have the ability to react with extracellular and soluble proteins and to complex with bacterial cell walls leading to the death of the bacteria (Cowan., 2002).

Steroids are antioxidants and they are active against bacterial activity (Okwu., 2001).

Glycosides will mostly remain inactive until they are hydrolysed to release an aglycone (phenols, terpenes, steroids and quinines) that has the active effect.

\section{Fourer Transform Infrared Sprectroscopy}

The FTIR results of the hexane and ethanol extracts showing the peak values, bond stretch and functional groupsis shown in Table 2. Various absorptions were observed in the two extracts of Callophylum inophyllum. The strong absorption at $3265.3 \mathrm{~cm}^{-1}$ corresponds to $\mathrm{O}-\mathrm{H}$ stretch which was observed in the ethanol extract only. $\mathrm{C}=\mathrm{O}$ stretch was observed in $1742.5 \mathrm{~cm}^{-1}$ and $1701.5 \mathrm{~cm}^{-1}$ in both extracts. The absorption at $1377.3 \mathrm{~cm}^{-1}$ corresponds to N-O stretch which was observed in the hexane extract only $=\mathrm{C}-\mathrm{H}$ of alkenes was observed in $3006.1 \mathrm{~cm}^{-1}$ in hexane extract only. The strong absorption at $2853.3 \mathrm{~cm}^{-1}, 2929.7 \mathrm{~cm}^{-1}, 2922.2 \mathrm{~cm}^{-1}$ and $2976.3 \mathrm{~cm}^{-1}$ corresponds to the $\mathrm{C}-\mathrm{H}$ stretch of alkanes found in both extracts. $\mathrm{C}-\mathrm{H}$ bending was observed in $1407.1 \mathrm{~cm}^{-1}, 1449.9 \mathrm{~cm}^{-1}$ and $1116.3 \mathrm{~cm}^{-1}$ in the ethanol extract only. $\mathrm{C}=\mathrm{C}$ stretch of aromatics was observed in $1578.5 \mathrm{~cm}^{-1}$ and $1459.3 \mathrm{~cm}^{-1}$ in both extracts. $C=C$ stretch of alkenes were observed in $1654.9 \mathrm{~cm}^{-1}$ and $1625.1 \mathrm{~cm}^{-1}$ in hexane extract only. C-N stretch of amines was observed in $1347.4 \mathrm{~cm}^{-1}, 1235.6 \mathrm{~cm}^{-1}$ and $1312.0 \mathrm{~cm}^{-1}$ in both extracts. C-O stretch of ether was observed in $1079.1 \mathrm{~cm}^{-1}, 1097.7 \mathrm{~cm}^{-1}, 1118.2 \mathrm{~cm}^{-1}$ and $1159.2 \mathrm{~cm}^{-1}$ in both extracts. $=\mathrm{CH}$ bending of alkenes was observed in $855.2 \mathrm{~cm}^{-1}$ in hexane extract only. $=\mathrm{CH}$ stretch of alkenes was observed in $721.2 \mathrm{~cm}^{-1}, 928.1 \mathrm{~cm}^{-1}, 885.2 \mathrm{~cm}^{-1}$ in both extracts. CF and C-Cl stretch of alkyl halides were observed in 10399 $\mathrm{cm}^{-1}$ and $697.0 \mathrm{~cm}^{-1}$ respectively in both extracts.

\section{Fatty Acids}

From the GC analysis of the hexane extract in Table 3 the results of the GC analysis showing the peak area and the percentage composition of the 12 fatty acids identified in varying proportionsare described below:

Lauric acid (3\%): It is a 12 carbon antimicrobial fatty acid which has the ability to kill harmful pathogens like bacteria (Nakatsuji et al., 2009).

Pentadecanoic acid (0.3\%): It is a 15 carbon fatty acid that is rare in nature (Rolf, 2002). 
Stearic acid (8.03\%): It is an 18 carbon fatty acid that has found many applications ranging from its use in cosmetic products, as food additives, in soaps and detergents, lubricants. It has the ability to react with some metals and form products of great values such as reaction with calcium to for calcium stearate, which functions as a release agent, with zinc to form a lubricant known as zinc stearatje (Tsenga et al., 1999).

Oleic acid (17.63\%): It is an 18 carbon atom that is present in the fat of all foods and is also produced from essential fatty acids in normal human liver cells and fat cells. It has the highest percentage of fatty acids found in Calophyllum inophyllum hexane extract. It reduces blood pressure, increases fat burning to help with weight loss, protects cells from free radical damage, may also prevent type 2 diabetes (Vassilious et al., 2009).

Linoleic acid (16.67\%): Linoleic acid is an essential fatty acid, a carboxylic acid, a polyunsaturated omega-6 fatty acid whose low levels indicate dietary insufficiency, which can lead to a variety of symptoms such as Eczema-like skin eruptions, loss of hair (Skolinik et al., 1977) liver degradation, behavioural disturbances, kidney degeneration, increased thirst, frequent infections, poor wound healing, sterility, miscarriage, arthralgia, cardiovascular disease, growth retardation. (Skolinik et al., 1977, Emily L.G., and Rajani K., 2017). It has a physiological role in maintaining the water permeability barrier of the skin as a constituent of acylglycosyl ceramides, it also gives rise to arachidonic acid, which is a major precursor of a series of bioactive metabolites called eicosanoids, which regulate a lot of physiological processes (Thomas, 2016).

Arachidonic acid ( $0.2 \%)$ : Arachidonic acid is not an essential fatty aid. It only becomes relevant if there is inability to convert linoleic acid to arachidonic acid (Rivers et al., 1975).

Behenic acid $(0.05 \%)$ : is a saturated fatty used for hair conditioners and moisturizers Lignoceric acid or tetracosanoic acid $(0.04 \%)$ is a 24 carbon fatty acid.

\section{Conclusion}

This study shows that Calophylluminophyllum hexane and ethanol seed extracts contain large amounts of phytochemicals with a possibility of wide range of biological activities such as antimicrobial, antiviral, cytotoxic, analgesic and against other disorders in favor of public health.

Gas Chromatography test carried out to identify the presence of fatty acids in Calophyllum inophyllum hexane seed extract discovered eight (8) fatty acids present namely: Lauric, Pentadecanoic, Stearic, Oleic, Linoleic, Arachnidic, Behenic, Lignoceric and absence of Tridecanoic, Myristic, Palmitic, Tricosnoic

It is recommended that further studies should be carried out using different solvents and other species in the Clusisceae family so as to obtain new and better results which may further be used in the production of drugs for diseases whose cure are yet to be found also aside the application in the production of biodiesel other applications especially in the production of cosmetics should also be researched into.

\section{References}

i. Akter, S., Bulbul, I., Hossain, S., Begum, Y., (2017). Pharmacological Study of Medicinal plant Calophyllum inophyllum L. on Swiss Albino Mice in the management of Pain and Inflammation. EJMP, 18(2): 1-10

ii. Cowen D.V. (1984). Flowering trees and shrubs in India. Thacker and Co. Ltd. Bombay.

iii. Emlily L.G., and Rajani Katta (2017) Diet and hair loss: effects of nutrient deficiency and supplement use. Dermatology Practical and Conceptual. 7(1):1-10

iv. Evans, W.C. (1989).Trease and Evans' Pharmacognosy. 13th edition.Balliere Tindall, London pp. 100-101

v. Friday, J. and Okano, D. (2006). Calophyllum inophyllum (kamani), ver.2.7.In: Elevitch, C.R. (Eds.). Species Profiles for Pacific Island Agroforestry. Permanent Agriculture Resources (PAR), Holualoa, Hawai'i.

vi. Govindachari, T.R., Viswanathan, N., Pai, B.R., Rao, U.R., and Srinivasan, M. (1967). Triterpenes of Calophyllum inophyllum linn. Tetrahedron 23, 1901-1910.

vii. Harborne, J.B., (1973). Phytochemical Methods: A Guide to Modern Techniques of Plant Analysis. 1st Edn., Chapman and Hall, London, UK. Pages: 271

viii. Hathurusingha H.M.S.D, Ashwath N., (2007) Beauty leaf, a tree with great economic potential. In: 12th international forestry symposium, Kalutara, Sri Lanka

ix. Hay, A.-E., Hélesbeux, J.-J., Duval, O., Labaïed, M., Grellier, P., and Richomme, P. (2004). Antimalarial xanthones from Calophyllum caledonicum and Garcinia vieillardii. Life Sci. 75, 3077-3085.

x. Hedberg I., Hedberg O., Madati P. J., Mshigeni K. E., Mshiu E. N., Samuelsson G., (1983). Inventory of plants used in traditional medicine in Tanzania. II. Plants of the families of Dilleniaceae--Opilliaceae.

xi. Ito, C., Itoigawa, M., Mishina, Y., Filho, V., Enjo, F., Tokuda, H., Nishini, H., Furukawa, H., (2003). Chemical constituents of Calophyllum brasiliense. 2. Structure of three new coumarins and cancer chemopreventive activity of 4-substituted coumarins. J. Nat. Prod. 66, 368-371.

xii. Itoigawa, M., Ito, C., Tan, H.T.-W., Kuchide, M., Tokuda, H., Nishino, H., and Furukawa, H. (2001). Cancer chemopreventive agents, 4-phenylcoumarins from Calophyllum inophyllum. Cancer Lett. 169, 15-19.

xiii. Laure, F., Raharivelomanana, P., Butaud, J.-F., Bianchini, J.-P., and Gaydou, E.M. (2008). Screening of anti-HIV-1 inophyllums by HPLC-DAD of Calophyllum inophyllum leaf extracts from French Polynesia Islands. Anal. Chim. Acta 624, 147-153.

xiv. Ma, C., Chen, B., Qi, H., Li, B., Zhang, G., (2004). Two pyranocoumarins from the seeds of Calophyllum polyanthum.J. Nat. Prod. 67, 1598-1600. 
xv. McKee, T., Civington, C., Fuller, R., Bokesch, H., Young, S., Cardellina II, J., Kadushin, M., Soejarto, D., Stevens, P., Cragg, G., Boyd, M., (1998). Pyranocoumarins from tropical species of the national cancer institute collection. J. Nat. Prod. 61, 1252-1256.

xvi. Monika, W. H., Joseph, S. and Teresa, K., (2008). Thin layer chromatography in phytochemistry.

xvii. Nakatsuji, T., Kao, M., Fang, J., Zouboulis, C., Zhang, L., Gallo, R., Huang, C., (2009). Antimicrobial property of Lauric Acid against Propionibacterium acnes: its Therapeutic Potential for Inflammatory Acne Vulgaris.J Invest Dermatol. 129(10):2480-2488.

xviii. Nowak, J. Z. (2010). Anti-inflammatory pro-resolving derivatives of omega-3 and omega-6 polyunsaturated fatty acids. Postepy higieny i medycyny doswiadczalnej 64:115-32

xix. Okwu D. E.., (2001). Phytochemicals and vitamin content of indigenous species of south Eastern Nigeria. Journal of sustainable Agriculture and the Environment, vol 6, pp. 30-34.

xx. Oliver-Bever, B. (1986). Medicinal Plants in TropicalWest Africa. Cambridge University Press, XX.

xxi. Patil, A.D., Freyer, A.J., Eggleston, D.S., Haltiwanger, R.C., Bean, M.F., Taylor, P.B., Caranfa, M.J., Breen, A.L., and Bartus, H.R. (1993). The inophyllums, novel inhibitors of HIV-1 reverse transcriptase isolated from the Malaysian tree, Calophyllum inophyllum Linn. J. Med. Chem. 36, 4131-4138.

xxii. Prabakaran K, John Britto S. (2012)Biology, agroforestry and medicinal value of Calophyllum inophyllum L. (clusiacea): A review. Int.J. Nat. Prod. Res;1(2): 24-33.

xxiii. Quisumbing, E. (1951). Medicinal Plants of the Philippines. Department of Agriculture and natural Resources, Bureau of Printing, Manila.

xxiv. Ramos, M.J., Fernández, C.M., Casas, A., Rodríguez, L., Pérez, A. (2009). Influence of fatty acid composition of raw materials on biodiesel properties. Biores. Technol. 100, 261-268.

xxv. Rivers J. P., Sinclair A., Craqford.M.A., (1975). "Inability of the cat to desaturate essential fatty acids". Nature. 258(5531):171-3.

xxvi. Rolf Jots (2002). "Milk and Dairy Products" Ullmann's Encyclopedia of Industrial Chemistry, Wiley-VCH, Weinheim.

xxvii. Sartori, N.T., Canepelle, D., De Sousa Jr., Martins, D., (1999). Gastroprotective effect from Calophyllum brasiliense Canb. bark on experimental gastric lesions in rats and mice.J. Ethnopharmacol. 67, 149-156.

xxviii. Sekino, E., Kumamoto, T., Tanaka, T., Ikeda, T., and Ishikawa, T. (2004). Concise Synthesis of Anti-HIV-1 Active (+)Inophyllum B and (+)-Calanolide A by Application of (-)-Quinine-Catalyzed Intramolecular Oxo-Michael Addition. J. Org. Chem. 69, 2760-2767.

xxix. Skolink P., Eaglstei W.H., Ziboh V.A., (1977) Human essential fatty acid deficiency: treatment by topical application of linoleic acid. Arch Dermatol. 113(7): 939-941.

xxx. Sodipo, O.A., Akiniyi, J.A and Ogunbamosu, J.U., (2000). Studies on certain characteristics of extracts of bark of Pausinystalia johimbe and Pausinystalia macroreas (K. schum.) Pierre ex Beille. Global Journal of pure and Applied Sciences, vol. 6, no. 1, pp. 83-87, 2000.

xxxi. Sofowora, A., (1996). Medicinal Plants and Traditional Medicine in Africa. 2nd Edn.,Spectrum Books, Ibadan, Nigeria, pp: 112.

xxxii. Su X.H, Zhang M.L, Li L.G, Huo C.H, Gu Y.C, Shi Q.W., (2008). Chemical constituents of the plants of the genus Calophyllum. Chem. Biodiver.; 5: 2579-2608.

xxxiii. Thomas A.B. Sanders (2016) The Role of Fats in Human Diet: Functional Dietary Lipids. Food formulation, Consumer issues and innovation for Health. Woodhead Publishing Series in Food Science, Technology and Nutrition: $1-20$

xxxiv. Tsenga, W.J., Mo Liua, D., Hsub, C., (1999). "Influence of stearic acid on suspension structure and green microstructure of injection-molded zirconia ceramics". Ceramics International. 25(2): 191-195.

xxxv. Vassiliou E, K Gonzalez, A., Garacia C., Tadros, J.H., Chakraborty G and Toney J. H., (2009) Oleic acid and peanut oil high in Oleic acid reverse the inhibitory effect of insulin production of the inflammatory cytokine TNF- $\alpha$ both in vitro and in vivo systems. Lipids in Health and Disease. 8:25

xxxvi. Westendarp H., (2006). Effects of tannins in animal nutrition.

xxxvii. Yimdjo, M.C., Azebaze, A.G., Nkengfack, A.E., Meyer, A.M., Bodo, B., and Fomum, Z.T. (2004). Antimicrobial and cytotoxic agents from Calophyllum inophyllum. Phytochemistry 65, 2789-2795. 